\title{
Discinid brachiopod life assemblages: Fossil and extant
}

\author{
MICHAL MERGL
}

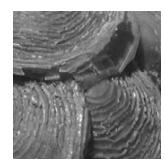

\begin{abstract}
Clusters of discinid brachiopod shells observed in Devonian and Carboniferous strata are interpreted as original life assemblages. The clusters consist of Gigadiscina lessardi (from Algeria), Oehlertella tarutensis (from Libya), Orbiculoidea bulla and $O$. nitida (both from England). Grape-like clusters of the Recent species Discinisca lamellosa and $D$. laevis are described and their spacing and size-frequency distribution are discussed. The possible function of clustering as protection against grazing pressure is suggested. Key words: Discinidae, Brachiopoda, life assemblages, palaeoecology, Devonian, Carboniferous, Libya, England, Discinisca, Orbiculoidea.
\end{abstract}

MergL, M. 2010. Discinid brachiopod life assemblages: Fossil and extant. Bulletin of Geosciences 85(1), $27-38$ (7 figures). Czech Geological Survey, Prague. ISSN 1214-1119. Manuscript received August 14, 2009; accepted in revised form January 18, 2010; published online March 8, 2010; issued March 22, 2010.

Michal Mergl, Department of Biology, University of West Bohemia, Klatovská 51, Plzeñ, 30614 Czech Republic; mmergl@kbi.zcu.cz.

Fossilized natural life assemblages of rhynchonelliform brachiopods have been recognized by many authors (e.g., Hallam 1961, Johnson 1977, Alexander 1994). Peculiar grape-like clusters of extant rhynchonelliformeans have been reported from New Zealand's fjords (Richardson 1997). A communal mode of life in monospecific clusters may also be recognized by the presence of Podichnus trace fossils (Bromley \& Surlyk 1973, Asgaard \& Bromley 1990, Robison \& Lee 2008).

Solitary discinid brachiopod shells in situ attached to various substrates are known from the Silurian to Recent (Davidson 1878, Thomson 1971, Richards 1974, Lockley \& Antia 1980, Bassett et al. 2009). However, Sowerby (1846) and Reeve (1862) followed by Davidson (1888) had already described and figured several complex natural clusters of extant discinid brachiopods. Their reports imply that such natural clusters are common in Discinisca lamellosa (Broderip, 1833) and Discinisca laevis (Sowerby, 1822) [= D. sowerbyi Muir-Wood, 1936]. Similar clusters have been described by Bassett et al. (2009) in the Recent Discinisca cf. tenuis (Sowerby, 1846) and the Ordovician discinid Kosoidea cedarbergensis Basset et al., 2009. LaBarbera (1985) described similar clusters of more than twelve individuals of Discradisca strigata (Broderip, 1833), while solitary individuals were reported as uncommon. In these clusters, the living individuals are attached to one another by a short pedicle. Due to taphonomic reasons, such as decay of soft tissues, there is only a slight probability that these complex life clusters are preserved in the fossil records. In addition, not all extant discinid brachiopods form aggregations. Paine (1962) found solitary shells of $D$. strigata on rock surfaces and a solitary habitat is common in other extant discinids. Solitary extant discinids attach to various hard substrates, such as rocky surfaces, pebbles, mollusc shells, whale bones, and manganese nodules (for review see Zezina 1961).

Several clusters of discinids, with shells in possible original life position, have been observed among Devonian and Carboniferous fossils. These clusters indicate that some extinct discinids had the same ecology and the same discoidal pedicle, adapted for fixation to hard substrates, as their extant relatives.

\section{Material}

The material studied is housed in the palaeontological collections of the Natural History Museum, London, Great Britain $(\mathrm{BMNH})$, the palaeontological collections of the $\mathrm{Mu}-$ seum of West Bohemia, Plzeň, the Czech Republic (ZCM), and the palaeontological collections of the Museum of Dr. B. Horák, Rokycany, the Czech Republic (MBHR).

\section{Description of fossil clusters}

Gigadiscina lessardi Mergl \& Massa, 2005

Figures 1, 2

Taxonomy. - See Mergl \& Massa (2005).

Geographical and geological setting. - The shells (ZCM S 03734/MAME 001) were collected by French geologists in 


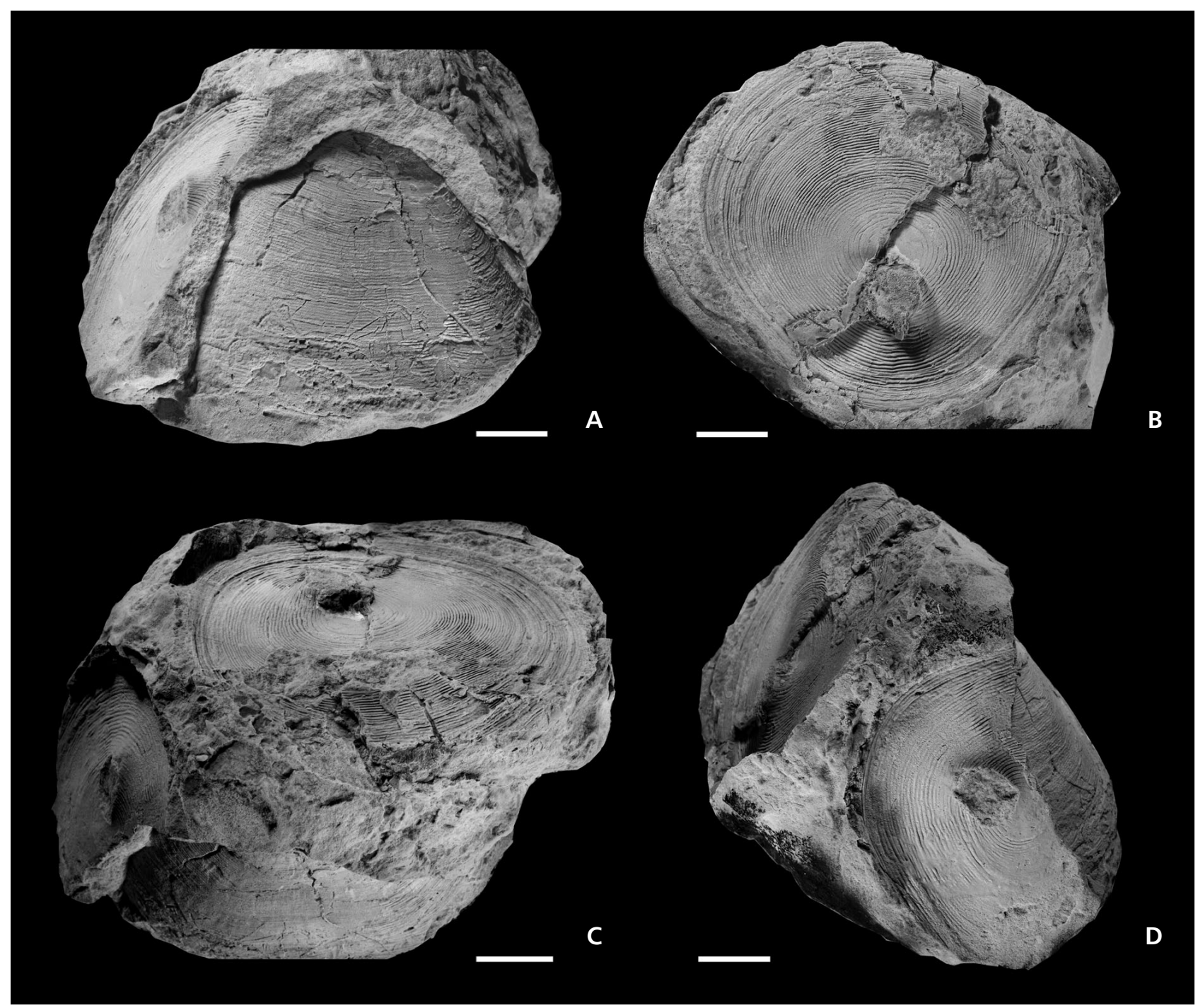

Figure 1. Cluster of Gigadiscina lessardi Mergl \& Massa, 2005. Lateral view of host specimen (A), the first (B) and the second (D) colonist specimens, and top view of the whole cluster (C). ZCM S 03734/MAME 001. Scale bar $10 \mathrm{~mm}$.

the In Rahir Tin Amzi section situated about $100 \mathrm{~km}$ west of In Guezzam in North Niger (sample H 1053; N19³8', E $4^{\circ} 45^{\prime}$ ). The basal unnamed Devonian unit which rests unconformably on Silurian bedrock, is probably of Pragian age. It is a local basal unit of the Devonian to Carboniferous marine sequence of the Tamesna Basin (Mergl \& Massa 2004, 2005).

Description. - The cluster of three specimens probably represents their original life position (Figs 1,2). The largest, a $60 \mathrm{~mm}$ long host specimen (Fig. 1A, right) presented a hard surface for two other similarly sized colonist specimens (Fig. 1C, left and top). The highly conical dorsal valve of the host individual bears two tightly attached planar ventral valves. These belong to conjoined specimens as suggested from the periphery of the dorsal valves preserved on the strip of rock on which an external mould of the margins of both conical dorsal valves are preserved. Two planar ventral valves of the colonists are inclined conformably at an angle to the host dorsal valve. The margins of the colonist shells do not overlap the commissure plane of the host specimen. The sizes of colonist specimens $(53 \mathrm{~mm}$ and $50 \mathrm{~mm}$ ) are similar to the size of the host specimen $(60 \mathrm{~mm})$. This minor difference indicates that the growth of the host specimen was retarded for a time compared with that of the colonist individuals.

The pedicle foramina of two colonist shells are elevated only $3-5 \mathrm{~mm}$ above the shell surface of the host specimen, indicating only a slight space between specimens. Judging from shell morphology, the pedicle of Gigadiscina lessardi protruded though a large circular subcentral foramen. There is no large, inward depressed area adjacent to the 
foramen, as is developed in some other discinid genera. The listrium is very restricted, forming only a small broadly triangular plate. It is thus suggested that the pedicle was short, sub-cylindrical, having a large adhesive area distally. In a retracted position, the inferred length of the pedicle extending from the foramen was only a few millimetres.

Taphonomy. - Apart from the described cluster, other available topotypic specimens (11 specimens) of Gigadiscina lessardi are represented by complete conjoined shells. Their preservation indicates little or no transport of the shells, and rapid burial in sand. The enclosing sediment is sandstone, with scattered rounded quartz grains up to $3 \mathrm{~mm}$ in size.

Synecology. - This species is associated with the large terebratulid Pleurothyrella sp. and another large discinid similar to Orbiculoides siegenensis Kayser, 1892, indicating the Malvinokaffric Realm (Mergl 2001). Upwards, a more diverse fauna of spiriferids, chonetids and trilobites appear, indicating a deeper-water environment. The fossil association represents a typical low-diversity, level bottom community in the shallow littoral zone. This suggests that the environment was similar to shallow-water Orbiculoidea dominated benthic communities of the Lower Devonian (Boucot 1975, Boucot et al. 2001). Similar giant discinids from temperate to cool marine environments of lower Devonian age (Rowell 1965, Boucot et al. 2001) are sometimes associated with terrestrial vertebrate remains corroborating their extremely shallow-water habitat.

Interpretation. - The fossils represent a life cluster where the colonist shells were fixed by a short pedicle to the similar sized host shell. The giant size of all individuals and shape of the shell, with moderate conical dorsal valve and planar ventral valve with subcentral pedicle opening, indicates adaptation for fixation to a hard substrate in a turbulent littoral environment (Mergl \& Massa 2005).

\section{Oehlertella tarutensis Havlíček, 1984}

Figures 3, 4G-K, 6A

Taxonomy. - See Havlíček (1984), Havlíček \& Röhlich (1987), and Mergl \& Massa (1992).

Geographical and geological setting. - The shells (MBHR C 1731) were collected by Czech geologists on the north flank of the Murzuq Basin in southwestern Libya. The fossil site is situated in the Eastern part of the Devonian and Carboniferous outcrop area, some $37 \mathrm{~km}$ east from Ashkidah (map-sheet 2280-II, locality C-11). The stratigraphic range of the species is restricted to the Tarut and Ashkidah

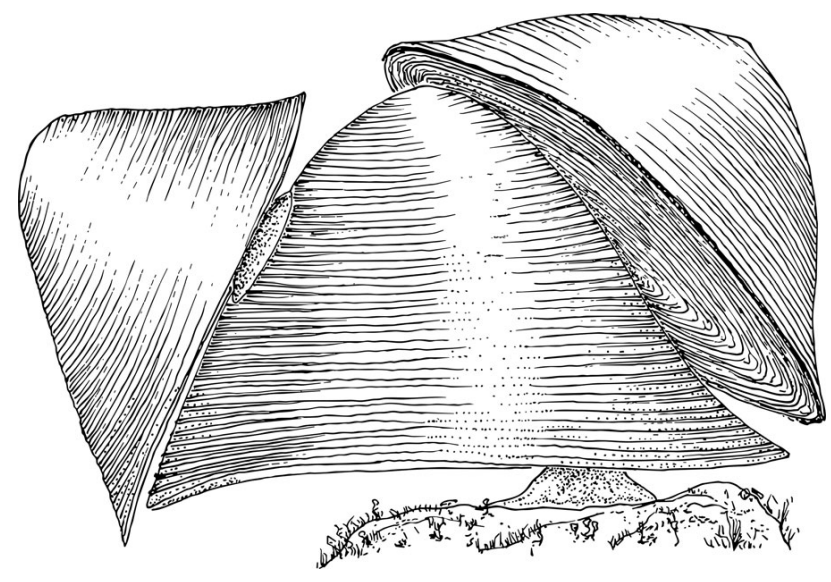

Figure 2. Reconstruction of a cluster of Gigadiscina lessardi Mergl \& Massa, 2005. Natural size.

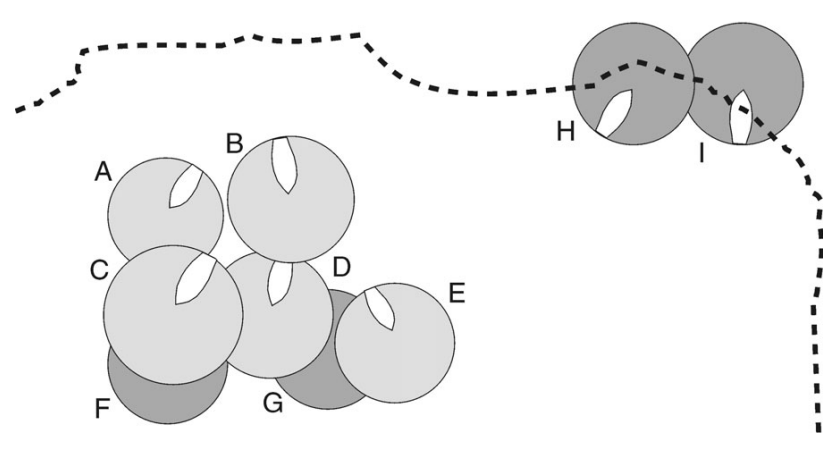

Figure 3. Cluster of Oehlertella tarutensis Havlíček, 1984. Specimen MBHR C 1731. Pale grey - specimens with dorsal valve above, dark grey - specimens with ventral valve above; dashed line - margin of slab.

formations (Havlíček \& Röhlich 1987), referred to the Late Devonian or Early Carboniferous transition units. Seidl \& Röhlich (1984) and Havlíček \& Röhlich (1987) presented precise stratigraphic and locality data.

Description. - Two clusters are preserved on the same rock (Fig. 3). The first cluster consists of seven conjoined specimens (Figs 3A-G, 4J). The shells are intact, preserved on a poorly defined bedding plate across an area of $30 \mathrm{~mm}$. There are two different shell orientations: five specimens have the ventral valves facing down, two specimens display the reverse orientation. The width of all the specimens ranges between 10 to $12.5 \mathrm{~mm}$. The body axes of the first group vary within $90^{\circ}$ (Fig. 6A). This clearly indicates a preferred orientation of individuals in the cluster. Large, spindle-shaped pedicle openings are in each case open and continue as a shallow hollow slit into the surrounding sediment. Preservation of all specimens is remarkably similar. The internal spaces inside the shells are empty and only a narrow strip along the shell periphery is filled by sandy matrix. This can be explained by rapid burial of live specimens with tightly closed shells. The presence of the pedicle and other soft tissues did not allow penetration of sediment 
through the pedicle slit and only a limited amount of sediment leaked into the closed shell. Consequently, soft tissues, including the pedicle, disappeared from the chamber after their decay.

Two other specimens (Fig. 3H, I) are less favourably preserved and display a reverse shell orientation compared with the specimens of the first group. The distance between both clusters is $35 \mathrm{~mm}$ and both clusters are on approximately the same bedding plane.

Taphonomy. - The suggested life cluster is preserved in fine ferruginous sandstone, lacking distinct bedding. Heavily weathered clay and haematite pebbles and fragmental bones of vertebrates form a substantial volume of the rock and indicate rapid deposition of the bed. The brachiopod shells are not broken, compressed or deformed, and are the only brachiopods present in the rock.

Synecology. - The species Oehlertella tarutensis is common in the Tarut and Ashkidah formations, being associated with bivalves Myalina, Lyriopecten, Leptodesma and others, a rhynchonellid brachiopod Cupularostrum arenosum, and a lingulid Wadiglossa wadigena. Placoderms, Aspidichthys and Macropetalichthys, and an acanthodian, Ctenacanthus, have also been identified (Seidl \& Röhlich 1984). The truncated autochthonous stems of lycopsids in ferruginous oolite bearing marine fossils have been observed in the Tarut Fm., indicating a swamp mangrove-like environment. Therefore, the Tarut and Ashkidah formations, except for the uppermost part of the latter unit, are interpreted as lagoonal, semilagoonal and swamp deposits (Seidl \& Röhlich 1984). Oehlertella tarutensis is also known from the summit of the Ashkidah Formation, which is characterized by a different, moderately diverse and wholly marine fauna with dominant rhynchonelliform brachiopods including the genera Syringothyris and Rhipidomella. This fauna is definitely of Early Tournaisian age.

Interpretation. - Both groups of shells likely represent an original life cluster of nine (or more) specimens, attached by the planar ventral valves to both sides of a common, soft and unpreserved substrate. It does not appear that the shells were attached to one another. The uniform sizes of shells indicates a population of the same age. The length of the pedicle of $O$. tarutensis cannot be reliably inferred, but most likely was less than $3 \mathrm{~mm}$.
Orbiculoidea bulla (McCoy, 1852)

Figures 4A, B, E

Taxonomy. - Graham (1972).

Geographical and geological setting. - The shells are derived from the material donated by Mr. C.T. Trechmann to the Natural History Museum, London in 1964 (BMNH B 54079-54085). The original label contains only the following data: Carboniferous, locality Redesdale, North (here specimens BMNH B 54083 and BMNH B 54085 are figured).

Description. - Two specimens probably represent an original life cluster (Fig. 4B, E). The host specimen (Fig. 4E, right) bears a similarly sized colonist specimen. In addition, three incomplete shells are preserved on the underside of the same nodule. The pedicle of the colonist specimen was fixed near the anterolateral margin of the host specimen. There are also other nodules (Fig. 4) with more than one specimen but their relationships are unclear. There are no additional data regarding the taphonomy and ecology of these samples.

Interpretation. - The sample of $O$. bulla probably represents an original life cluster, similar to clusters of related $O$. nitida. It is improbable, that the empty shells were displaced and swept together by bottom currents.

\section{Orbiculoidea nitida (Phillips, 1836)}

Figures 4C, D, F

Taxonomy. - Graham (1972).

Geographical and geological setting. - The shells are from the Etheridge collection, purchased by the Natural History Museum, London, in 1869. The original labels indicate that the specimens come from the Coal Measures at Coalbrookdale (specimens BMNH B 94039, BMHN B 94037). All specimens are preserved with the original shell in carbonate nodules.

Description. - Two natural groups are preserved. The first group of four specimens consists of an $18 \mathrm{~mm}$ long host shell with three much smaller colonist individuals attached

Figure 4. Clusters of Carboniferous discinids. - A-C - Orbiculoidea bulla (M'Coy, 1852). A - ventral valve with fragments of other valves, probably representing a life cluster, BMNH B 54083. B, C - two dorsal valves, probable a life cluster, BMNH B 54085. • D-F - Orbiculoidea nitida (Phillips, 1836). E, F - shell with three small shells attached (E) and detail of the attached shell (F), BMNH B 94039. D - cluster of three shells, BMNH B 94037. Scale bars $5 \mathrm{~mm}(\mathrm{~A}-\mathrm{E})$, and $2 \mathrm{~mm}(\mathrm{~F}) \cdot \bullet \mathrm{G}-\mathrm{K}$ - Oehlertella tarutensis Havlíček, 1984, specimen MBHR C 1731. G - two specimens (H, I) from the second cluster. $\mathrm{H}, \mathrm{I}, \mathrm{K}$ - details of preservation showing chamber in pedicle opening and partial infilling of interior by sediment in specimens $\mathrm{B}$, D and $\mathrm{C}$. $\mathrm{J}$ - seven specimens $(\mathrm{A}-\mathrm{G})$ from the first cluster. Scale bar $5 \mathrm{~mm}(\mathrm{G}-\mathrm{K})$. 


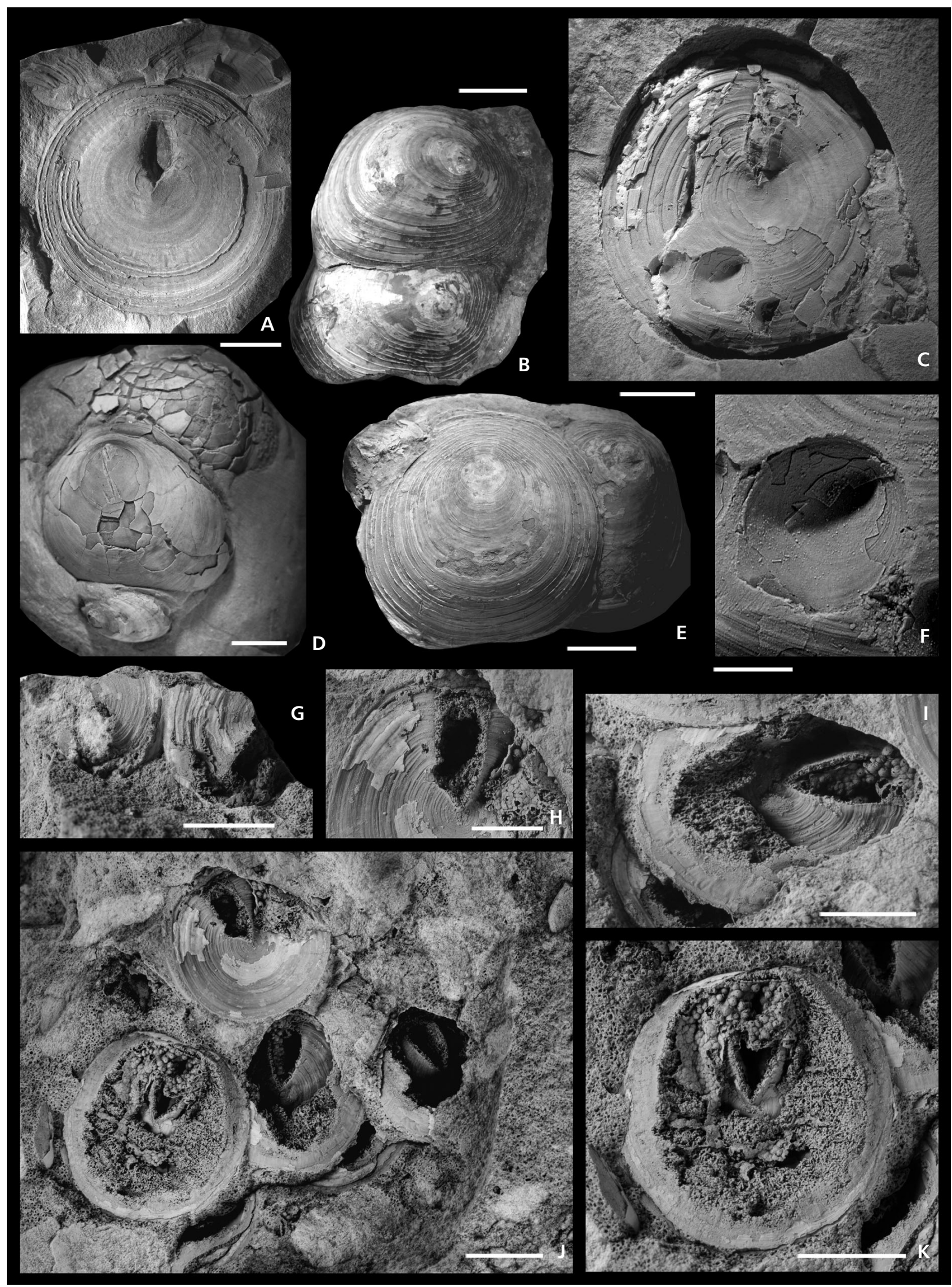


(Fig. 4C, F). The almost planar ventral valve is preserved as an external mould. The original presence of the dorsal valve is indicated by its partial external mould. Three small individuals of the same species are preserved on the outer surface of the host ventral valve. All are located on the anterolateral part of the valve. The colonist specimens are $2.4 \mathrm{~mm}, 3.0 \mathrm{~mm}$ and $4.3 \mathrm{~mm}$ long, respectively. Their anterior margins are orientated anterolaterally in two specimens, and the reverse orientation is displayed in the third specimen. This indicates a preferred shell orientation.

The second example (Fig. 4D) consists of three dorsal valves. The ventral valves are not visible but it is probable that all specimens represent conjoined individuals. The host specimen is $c a 18 \mathrm{~mm}$ long. It is poorly preserved, with the shell partly collapsed and bearing the first colonist of a comparable size and convexity. The second colonist specimen is fixed to the surface of the first colonist. It is less than half size in comparison with the two other specimens. The sites of fixation of the colonist individuals are located on the anterior slopes of the host specimen. The body axes of all specimens are within a $90^{\circ}$ arc. This indicates some preferential orientation of colonist individuals. There are no data regarding the taphonomy and ecology of these samples.

Interpretation. - Both aggregations probably represent original life clusters. The fixation of small individuals to the underside of the planar ventral valve indicates a sufficient gap between the substrate and the underside of the host shell. The space was not less than 2-3 mm because the apices of the attached small individuals are unworn. However, the extent of the gap was the definite limit for growth of the attached individuals. One can speculate that the largest attached individual was close to the gap maximum. Growth on the exterior of the dorsal valves, inferred from the second cluster, has no size limit. Therefore the first colonist shell in the second described group is nearly the same size as the host shell. The second colonist is only half-sized and represents a younger, not fully grown specimen.

The pedicle of the species was probably short, but may have extended to $2-3 \mathrm{~mm}$ in length, as there is enough space for the small specimen below the ventral valve and substrate.

\section{Description of Recent clusters}

\author{
Discinisca lamellosa (Broderip, 1833) \\ Figures 5A-D, 6B
}

Taxonomy. - Reeve (1862), and Davidson (1888).

Material. - Two natural clusters of specimens were collected by Mr. H. Cumming between Ecuador and Colombia, probably in the Gulf of Ancon (BMNH Pal. PI ZB 1251) and in the Ancon Bay, Peru (BMNH Pal. PI ZB 11) (after Reeve 1862), respectively. A third smaller cluster is "possibly from Peru" as indicated by the attached label (BMNH Pal. ZB 68).

Description. - Two of the three groups consist of more than 20 specimens. The first cluster (BMNH Pal. PI ZB 11) consists of 10 large specimens (length 15-23 mm, the host specimen is $23 \mathrm{~mm}$ long) and more than 18 smaller specimens. The second large group consists of $c a 25$ specimens. The third cluster (BMNH Pal. ZB 68) consists of 12 specimens.

The dimensions of the specimens vary significantly in all the clusters. There are shells less than $1 \mathrm{~mm}$ long. These shells are often fixed between the concentric lamellae of a larger specimen. The smaller shells are also located in crevices and gaps between larger shells. Colonist specimens of all size groups are generally attached to the upper side of the host specimen but several individuals are also attached to the underside of the host specimen. Underside specimens display a distinct preference for fixation near the anterior periphery of the host individual. There is a clear radial arrangement of the attached shells (Figs 5D, $6 \mathrm{~B})$. The colonist underside specimens have a tendency to be more inclined, less regular, having convexo-concave profiles to their ventral valves. Frontal margins of the colonist shells are extended far behind the margin of the host shell. The upper side colonist shells display a preferred attitude, with their body axes directed toward the apex of the host specimen. Planes of commissure of colonist shells broadly diverge from that of the host specimen. There are specimens having almost vertical commissures compared with the host specimen.

Ecology. - The figured clusters of Discinisca lamellosa were, following data presented by Reeve (1862), collected

Figure 5. Clusters of Recent discinids. • A-C - Discinisca lamellosa (Broderip, 1833), BMNH Pal. PI ZB1251, locality Gulf of Ancon, figured by Davidson (1888) on pl. 26, fig. 6, upper side (A), lower side (C) and side view (B) of cluster. $•$ D - Discinisca lamellosa (Broderip, 1833), BMNH ZB 68, exact locality unknown ("possibly from Peru"), host specimen with radially arranged colonist specimens. $・$ E-I - Discinisca laevis (Sowerby, 1822), BMNH Pal. PI ZB 3623, locality Callao, Peru, figured by Davidson (1888) on pl. 26, fig. 10, upper (E) and lower (F) side of cluster, with host specimen at the top, lower $(\mathrm{G})$ and upper $(\mathrm{H})$ side of cluster originally attached to host shell (site marked by arrow), and juvenile specimen (I). $\bullet \mathrm{J}-\mathrm{L}-$ Discinisca laevis (Sowerby, 1822), BMNH Pal. PI ZB 1235, locality Chile, figured by Reeve (1862), pl. 1, fig. 5, two shells (J) originally attached to cluster (K), and a juvenile specimen (L). Scale bar $5 \mathrm{~mm}(\mathrm{~A}-\mathrm{L})$. 
Michal Mergl • Discinid brachiopod life assemblages: Fossil and extant
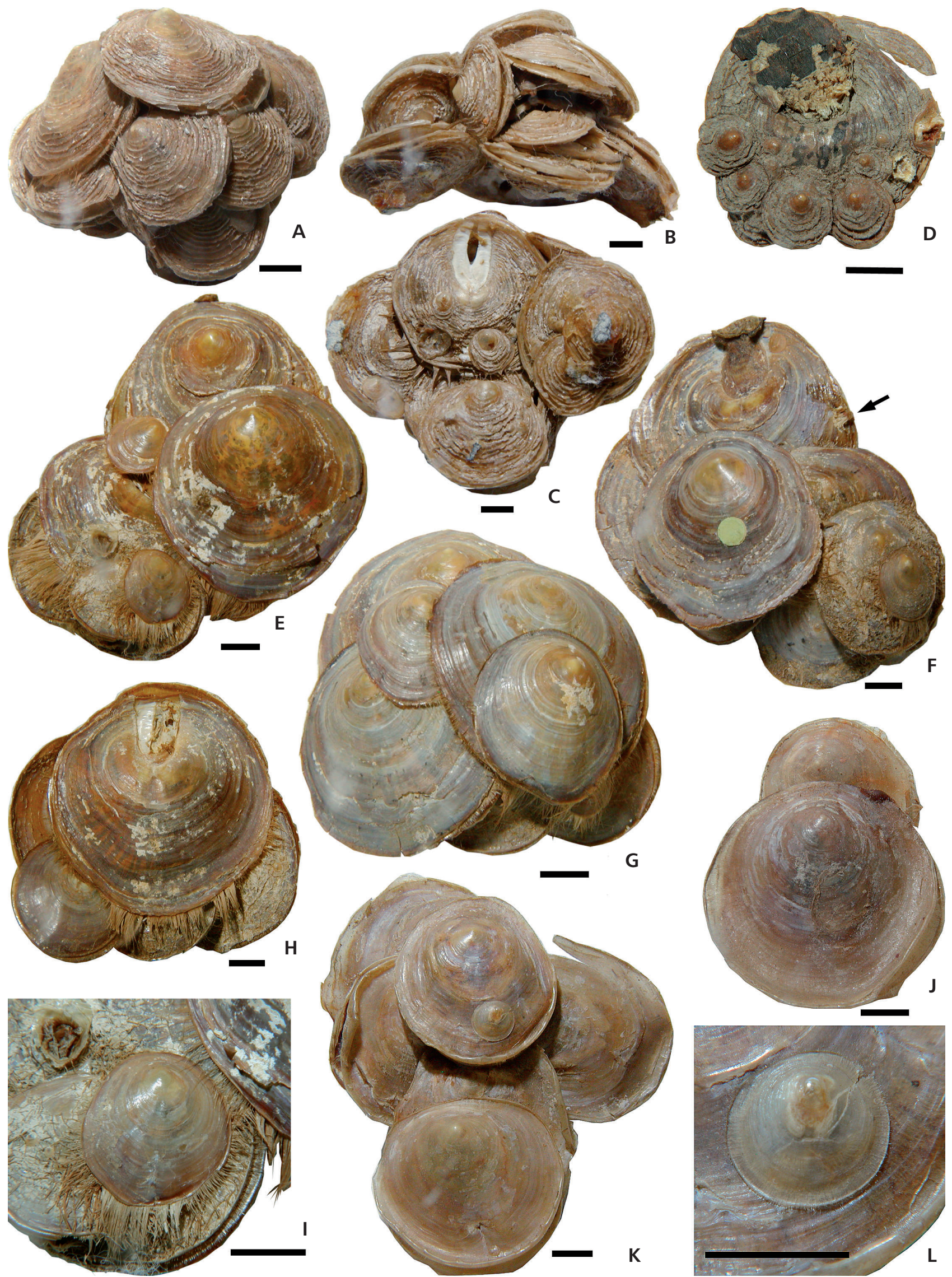
from a depth of 9 to $17 \mathrm{~m}$. According to this author, the species formed layered clusters on a sandy substrate. Modern data from Callao, Peru (Argüelles et al. 2002, Pacheco \& Garate 2005) indicate, that Discina lamellosa, often found in clusters, is one of the dominant invertebrates in subtidal megabenthos, together with the bivalve Semimytilus algosus.

Remarks. - There are some previously published figures of two clusters in the older literature. One group was described and illustrated by Reeve (1862, pl. 1, fig. 3). The second group, figured by Sowerby (1846, pl. 73, fig. 1) was re-drawn by Davidson (1888, pl. 26, fig. 6), and is re-figured here in Fig. 6A-C. Another similar cluster from Callao, Peru was figured by Rowell (1965) and Holmer \& Popov (2000).

\section{Discinisca laevis (Sowerby, 1822)}

Figures 5E-L, 6C, D, 7

Taxonomy. - Sowerby (1822), Reeve (1862), Davidson (1888), and Muir-Wood (1936).

Material. - The natural cluster of specimens (BMNH Pal. PI ZB 3623) was collected at Callao, Peru. The second smaller cluster (BMNH Pal. PI ZB 3624) is from Conception Island, Chile. The third cluster (BMNH Pal. PI ZB 1535) was collected by Mr. H. Cumming on the coast of Chile (after Reeve 1862).

Description. - The first cluster consists of 24 preserved specimens (Fig. 5E-I). All specimens are conjoined, forming three size groups. The first size group consists of four specimens with lengths ranging from 27 to $30 \mathrm{~mm}$. These four individuals are attached to a single host specimen. The second group consists of 14 specimens with lengths ranging from 10 to $25 \mathrm{~mm}$. These specimens are attached to individuals of the first group, or to individuals within the second group. One specimen is also attached to the host specimen. The third group is represented by five specimens (at least) smaller than $6 \mathrm{~mm}$. These individuals were observed on shells of the first group. Attached specimens are attached to both dorsal and ventral valves, forming a complex grape-like aggregation (Fig. 7). The planes of commissure of all specimens are approximately the same. Shell orientation is clearly unidirectional, generally ranging within a $140^{\circ}$ arc. A second smaller cluster consists of four specimens of similar size. The different size clusters of attached specimens suggest three hatching episodes.

The third cluster consists of 10 specimens (currently broken into two pieces with eight and two specimens, respectively) (Fig. 5J-L). All specimens are conjoined, with approximately the same orientation of the apices except for one juvenile specimen (Fig. 5L). There are two sizegroups. The first consists of the larger specimens, with lengths ranging from 23 to $27 \mathrm{~mm}$. The second distinct size group is represented by two specimens, $6 \mathrm{~mm}$ and $3 \mathrm{~mm}$ long, respectively. The orientation of body axes ranges within $140^{\circ}$ ( 8 specimens measured) indicating some preference for shell attitude. The planes of commissure of all specimens have approximately the same orientation.

Remarks. - The first and second clusters were figured by Davidson (1888). In his figures (pl. 26, figs 10, 11) the large cluster is not split into two clusters. These clusters are now stored in the Natural History Museum (Fig. 4F, G). The remains of the pedicle of the host specimen in the second group is preserved near the lateral margin of the host specimen (Fig. 5F, right side of top specimen).

The third cluster has been described and figured by Reeve (1862). In his figure (pl. 1, fig. 5) the group consists of ten specimens. This cluster is now stored in the Natural History Museum and consists of two groups (Fig. $2 \mathrm{~K}, \mathrm{~L})$. It is identified by the label as Discinisca tenuis (Sowerby, 1846), following Reeve's (1862) original determination. However, Davidson (1888, p. 197) questioned this determination. It seems more likely that this cluster also belongs to D. laevis. The species D. tenuis occurs along the coast of Namibia (Hiller 1990, 1993) and there are no records of this species from the Pacific coast of South America.

\section{Discussion}

Solitary discinids, both fossil and extant, are fixo-sessile invertebrates, attached by a pedicle to various hard substrates. Since the Ordovician, the fossil record has included discinids attached to brachiopods (Cooper 1956, Bassett et al. 2009), bivalves (Davidson 1888), cephalopods (Havlíček 1972, Lockley \& Antia 1980, Gabbott 1999), conulariids (Mergl 2006), plant debris (Thomson 1971) and chondrophorans (Richards 1974, Hannibal 2003). Observations of Recent discinids indicate a cryptic mode of life on the underside of cobbles (Paine 1962) or even an infaunal mode of life on the underside of large boulders deeply embedded in coarse sand (Kato 1996). On these substrates, the discinids sometimes form aggregations of uniformly-sized individuals or have bimodal or polymodal distributions indicating separate recruitment episodes (Richards 1974). Considering extant discinids, only LaBarbera (1985) has described in detail the behaviour of the extant Discinisca strigata. Many of his observations could be applied to the clusters described here.

Clustering. - Extant discinids pursue a solitary life mode (Paine 1962) or form clusters (LaBarbera 1985). The ob- 
servations of LaBarbera (1985) on clusters of Discradisca strigata indicate its ability to prevent or repress the growth of competitive invertebrates by the abrasion and wear of epifauna (sponges, bryozoans, serpulids) and depletion of nutrients in the locally circulating water. The mechanical wear is generated by the greater hardness of the organophosphatic shell and by the shell rotation on the pedicle. This rotation may describe a $60-150^{\circ}$ arc. The rotation with extended setae also mechanically inhibits sponge and bryozoan growth by directly damaging their tissues. Another suggested competitive mechanism is the improvement in feeding by utilization of anterior setae to form an incurrent siphon extended above and near suspension feeding epifauna. Clusters described by LaBarbera (1985) consisted of between two to over a dozen animals; some bore young $D$. strigata.

The described cluster of Oehlertella tarutensis probably represents a similar aggregation of specimens of the same age, attached to a plant or other unfossilized substrate. The substrate was utilized by the numerous larvae from a single hatching event. The individuals were not significantly affected by one another during growth. Their shell surface probably did not represent an attractive substrate for settlement of larvae. The reasons for formation of monospecific grape-like clusters are less clear. There are suggestions of larval settlement preferences (Wilson 1958) or poor dispersal power (Blochmann 1908). Some groups of described discinids (D. nitida) are superficially similar to clusters of the marine gastropod Crepidula. Grouping of these gastropods is associated with a higher probability of fertilization by males attached to host female specimens. However, it does not seem likely, that discinids have the same reason for clustering. According to the present author, the hard, relatively stable, raised substrate of the shell is advantageous in minimizing predation stress. The settlement of the larvae in crevices between already existing shells and their lamellae increases the chance of juvenile survival. Unlike a bare rock surface, the surface of moderate-sized shells attached by a pedicle or a byssus (e.g., brachiopod shells or pectinid bivalves) and elevated above the surface probably decreases grazing pressure from chitons, gastropods and echinoids. According to Asgaard \& Bromley (1990), grazing is a major limiting factor in distribution of the Recent micromorphous terebratellacean Argyrotheca in the Mediterranean Sea. However, clustering is probably not efficient against predation by larger predators, such as the rock-lobster Jasus lalandii which is a main predator of bivalves and Discinisca tenuis along the Namibian coast today (Hiller 1993).

Orientation. - Both in fossil and recent clusters, a preferred orientation of the body axis is evident (Fig. 6). This may be explained by a preference of discinids to orientate the shell
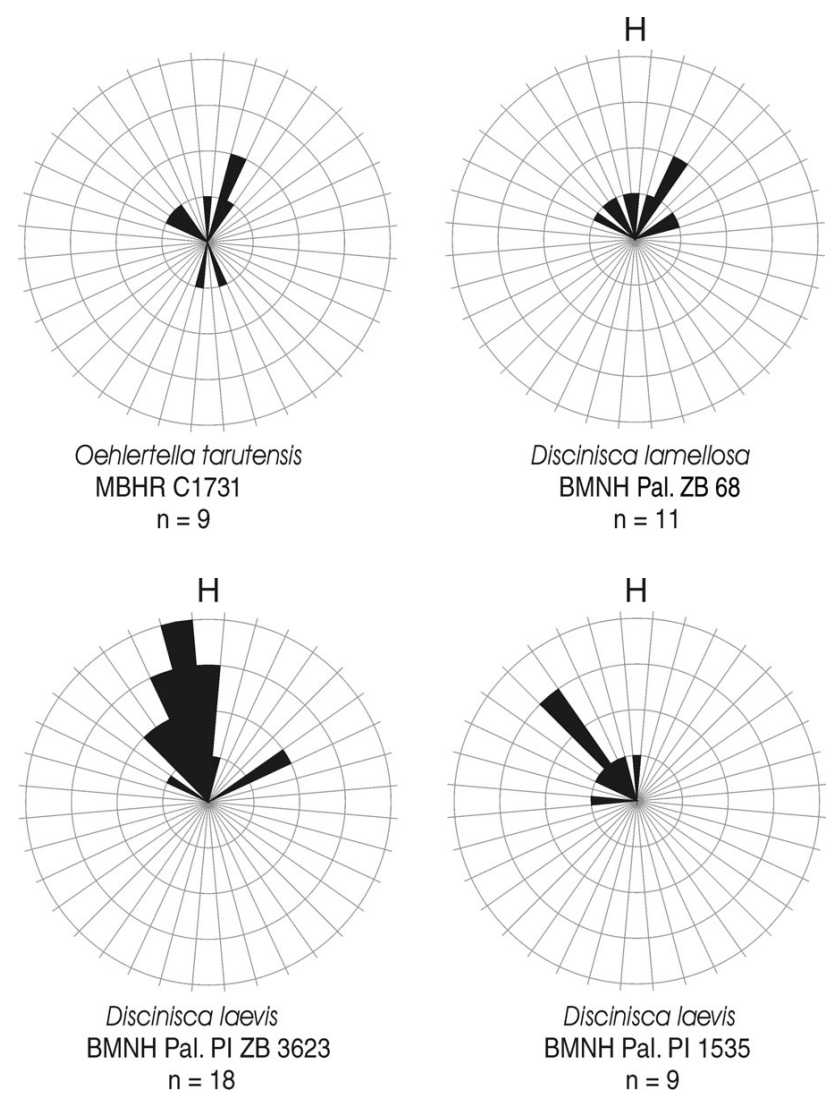

Figure 6. Rose-diagrams of orientation of body axes in discinid clusters; $\mathrm{n}$ - number of specimens, $\mathrm{H}$ - host specimen.

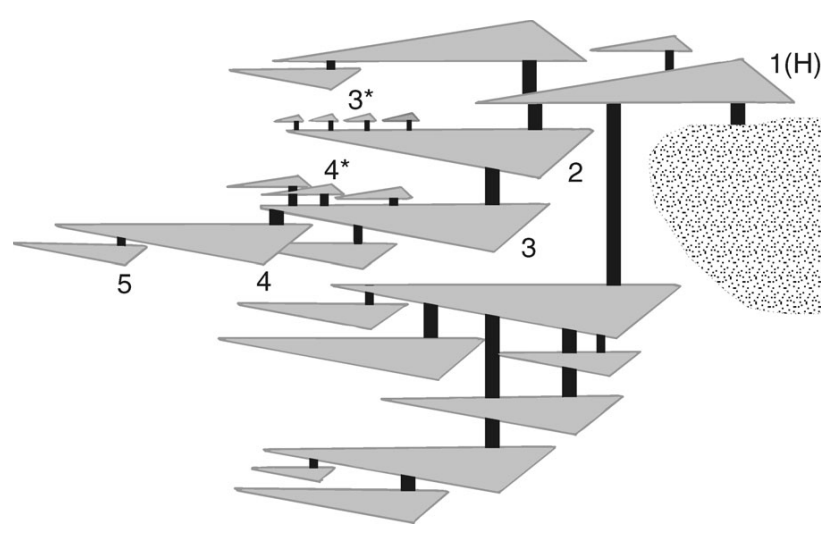

Figure 7. Diagram of a grape-like cluster of Discinisca laevis (Sowerby, 1822), specimen BMNH Pal. PI ZB 3623. Note five or six generations: $1(\mathrm{H})$ - host specimen; 2-5 - longest chain of four colonist specimen; $3^{*}, 4^{*}$ - groups of small specimens.

and lophophore relative to water currents (LaBarbera 1985), and can be used as a criterion for recognition of original life aggregations. However, the apex of the ventral and dorsal valve, respectively, may not always show the same alignment, because discinids are able to rotate the dorsal valve in a large arc relative to the ventral valve (LaBarbera 1985). 
Shell size and life span. - There are few data about the life span of Recent discinoids. La Barbera (1985) suggested that the studied adult populations of D. strigata are over ten years old even though size of specimens in its clusters did not surpass $15 \mathrm{~mm}$. The same size range is present in the fossil cluster of Oehlertella tarutensis. Unlike D. strigata where juvenile specimens under $2 \mathrm{~mm}$ were present, the cluster of $O$. tarutensis contains uniformly sized individuals and probably represents a single hatching episode. A similar uniformity of shell size is seen in the Gigadiscina lessardi cluster. The colonist shells of this species are remarkably large and nearly the same size as the host individual. Similar features are seen in extant Discinisca lamellosa and D. laevis. It is unlikely, that colonist and host shells could be the same age. The colonist shells attached to large, almost adult shells, as is evident from the fixation of colonist shell pedicles near the margin of the host shell. Active creeping by means of the pedicle on the host specimen surface or moving from one shell to another is unlikely. The size uniformity of the host and attached specimens could be explained by competition for food. The host specimen is deprived of food by the feeding of colonist individuals with their shell margins extended over the margin of the host specimen. Thus, the growth of the host specimen is retarded compared to that of the colonist specimens. The much smaller juvenile specimens, abundant on the surface of extant species (Fig. 5C, D, K) do not significantly affect the feeding ability of large individuals. These much smaller specimens probably represent another hatching event. Bimodal size distribution of the host and colonist specimens is also seen in Orbiculoidea bulla and O. nitida clusters as reported by Richards (1974) and in the Pennsylvanian Orbiculoidea newberryi Hall. The bimodal distribution of Kosoidea cedarbergensis Basset et al., 2009 is noted by these authors. In the extant species (Fig. 7), there are approximately three to five size ranges in the clusters, which represent separate generations (Williams et al. 2001).

Length of pedicle. - Südkamp (1997) described finds of Orbiculoidea? mediorhenana Fuchs, 1915 with remarkably long pedicles, but its pedicle size is probably a preservational artefact (Otto 2000). A rather short pedicle can be inferred for the late Ordovician discinid Kosoidea (Bassett et al. 2009). The mode of preservation of the Devonian and Carboniferous clustered discinids also indicate the presence of short pedicles, basically similar to that of Recent Discina (Blochmann 1900).

\section{Conclusions}

Shell morphology and ecological behaviour such as an epifaunal style of life, clustering of equally-sized specimens, aggregation into grape-like clusters, presence of two or more size-groups in discinid clusters, orientation of shells in clusters, the predicted length and shape of pedicle suggest that there is a continuity of soft-body morphology and basic life style within the discinoid clade throughout a major part of the fossil record, at least from the Early Devonian. It is suggested, that formation of grape-like clusters is a response to grazing predators. The initial survival of juveniles attached to elevated host shells or floating objects is more probable than if on surfaces accessible to grazing.

There is an obvious higher morphological uniformity amongst post-Devonian discinoids. These invariably possess a planar ventral valve, conical dorsal valve and a sucker-like pedicle. The Ordovician, Silurian and Devonian discinoids exhibit much higher morphological disparity (Cooper 1956; Bassett 1986; Mergl 2001, 2006, 2008, 2009; Valentine et al. 2003) that reflects more diverse habitats and feeding behaviors. The cause of this decrease morphological disparity is unclear, but higher predation pressure from grazing molluscs, vertebrates and competition from byssate bivalves from the Devonian Period onwards could have been important.

\section{Acknowledgements}

The author is greatly indebted to Sarah Long who kindly allowed access to specimens in the Natural History Museum, London and to David Harper and Arthur Boucot for reviews which significantly improved the manuscript. Research was funded by a grant from the Grant Agency of the Czech Republic, GAČR 205/07/0466: Origin and evolution of the discinoid brachiopods in the Palaeozoic.

\section{References}

ALEXANDER, R.R. 1994. Distribution of pedicle boring traces and the life habit of Late Palaeozoic Leiorhynchid brachiopods from dysoxic habitats. Lethaia 27, 227-234.

DOI $10.1111 /$ j.1502-3931.1994.tb01414.x

ARGÜElles, J., ZAVALA, J., TAIPE, A. \& TAFUR, R. 2002. Community structure changes of subtidal macrobenthis of hard substrate from Palomino Isle, Callo - Perú, from 1997 to 2001. Investigaciones marinas 30,1 .

AsGAARD, U. \& BROMLEY, R.G. 1991. Colonization by micromorph brachiopods in the shallow subtidal of the eastern Mediterranean Sea, 261-264. In MACKINNON, D.I., LEE, D.E. \& CAMPBELl, J.D. (eds) Brachiopods through Time. A.A.Balkema, Rotterdam \& Brookfield.

BASSETT, M.G. 1986. Brachiopodes Inarticules, 85-97. In RACHeBoeuf, P.R. (ed.) Le Groupe de Lievin, PridoliLochkovien de l'Artois (N. France). Biostratigraphie du Paleozoique 3.

BASSETT, M.G., POPOV, L.E., AldRIDGE, R.J., GABBOTT, S.E. \& THERON, J.N. 2009. Brachiopoda from the Soom Shale 
Lagerstätte (upper Ordovician, South Africa). Journal of Palaeontology 83(4), 614-623. DOI 10.1666/08-136.1

BOUCOT, A.J. 1975. Evolution and extinction rate controls. 427 pp. Elsevier, Balkema.

Boucot, A.J., Rowell, A.J., Racheboeuf, P., Pereira, E., GonçAlves de Melo, J.H. \& Peixoto de Siqueira, L. 2001. Position of the Malvinokaffric Realm's northern boundary (Early Devonian) based on newly discovered brachiopods from the Parecis Basin (Brazil). Journal of the Czech Geological Society 46, 109-120.

BRODERIP, W.J. 1833. Description of some species of Cuvier's family Brachiopoda. Zoological Society of London, Proceedings 1, 141-144.

BROMLEY, R.G. \& SURLYK, F. 1973. Borings produced by brachiopod pedicles, fossil and recent. Lethaia 6, 349-365. DOI 10.1111/j.1502-3931.1973.tb01203.x

BLOCHMANN, F. 1900. Untersuchungen über den Bau der Brachiopoden. I, Die Anatomie von Crania anomala O.F.M. (1892). Die Anatomie von Discinisca lamellosa (Broderip) und Lingula anatina (Bruguière). 124 pp. Gustav Fischer, Jena.

BlochmanN, F. 1908. Zur Systematik und geographishen Verbreiterung der Brachiopoden. Zeitschrift für wissenschaftliche Zoologie 90, 596-644.

COOPER, G.A. 1956. Chazyan and related brachiopods. Smithsonian Miscellaneous Collection 127, 1-1245.

DAVIDSON, T. 1878. A Monograph of the British Fossil Brachiopoda (Vol. 4, Part 2, No. 2: Supplement to the Jurassic and Triassic Species). Palaeontographical Society Monograph 32, $145-241$.

DAVIDSON, T. 1886-1888. A Monograph of Recent Brachiopoda, Parts I-III. Transactions of the Linnean Society of London, Series 2 - Zoology 4, 1-248. DOI $10.1111 / \mathrm{j} .1096-3642.1886 . t b 00655 . x$

FuCHS, A. 1915. Der Hunsrückschiefer und die Unterkoblenzschichten am Mitterrhein (Loreleigegend). Abhandlungen der Preussich geologichen Landesanstalt, Neue Folge 79, 1-79.

GAввотT, S.E. 1999. Orthoconic cephalopods and associated fauna from the Late Ordovician Soom Shale Lagerstätte. South Africa. Palaeontology 42, 123-148.

DOI 10.1111/1475-4983.00065

GRAHAM, D.K 1972. A review of the brachiopod genus Orbiculoidea in the Scottish Carboniferous. Bulletin of the Geological Survey of Great Britain 38, 43-58.

HALlAM, A. 1961. Brachiopod life assemblages from the marlstone rock-bed of Leicestershire. Palaeontology 4, 653-659.

HANNIBAL, J.T. 2003. Ancient mariners and their encrusters: identity, taphonomy and epizoa of "by-the-wind sailors" (Chondrophora) in the genus Plectodiscus. Geological Society of America Abstracts with Programs 35(5), 15.

HAVLÍČEK, V. 1972. Life habit of some Ordovician inarticulate brachiopods. Věstník Ústředního ústavu geologického 47, 229-234.

HAVlíčEK, V. \& RÖHLICH, P. 1987. Devonian and Carboniferous brachiopods from northern flank of Murzuk Basin (Libya). Sborník geologických věd, Paleontologie 28, 117-177.

HILLER, N. 1990. The southern African Recent brachiopod fauna. 439-445. In MACKINNON, D.I., LEE, D.E. \& CAMPBELL, J.D. (eds) Brachiopods through Time. A.A. Balkema, Rotterdam \& Brookfield.
HILlER, N. 1993. A modern analogue for the Lower Ordovician Obolus conglomerate of Estonia. Geological Magazine 130(2), 365-367. DOI 10.1017/S0016756800009912

HOLMER, L.E. \& POPOV, L.E. 2000. Lingulata, 30-146. In WILLIAMS, A., BRUNTON, C.H.C. \& CARLSON, S.J. (eds) Treatise on Invertebrate Paleontology, part H, Brachiopoda, Revised, Volume 2. Geological Society of America, Inc. \& University of Kansas Press, Boulder \& Lawrence.

JOHNSON, M.E. 1977. Succession and replacement in the development of Silurian brachiopod populations. Lethaia 10, 83-93. DOI 10.1111/j.1502-3931.1977.tb00595.x

KAYSER, E. 1892. Beitrage zur Kenntnis der Fauna der Siegenischen Grauwacke. Jahrbuch der köninglichen preussischen geologischen Landesanstalt 2(8), 95-107.

KATO, M. 1996. The unique intertidal subterranean habitat and filtering system of a limpet-like brachiopod, Discinisca sparselineata. Canadian Journal of Zoology 74(11), 1983-1988. DOI $10.1139 / \mathrm{z} 96-225$

LABARBERA, M. 1985. Mechanism of spatial competition of Discinisca strigata (Inarticulata, Brachiopoda) in the intertidal of Panama. Biology Bulletin 168, 101-105.

LOCKLEY, M.G. \& ANTIA, D.D.J. 1980. Anomalous occurrences of the Lower Palaeozoic brachiopod Schizocrania. Palaeontology 23(3), 707-713. DOI 10.2307/1541176

MCCOY, F. 1852. On some new Brachiopoda from the Carboniferous Limestone, Contributions to British Palaeontology. Annals Magazine of Natural History 2(10), 421-429.

MERGL, M. 2001. Lingulate brachiopods of the Silurian and Devonian of the Barrandian. Acta Musei nationalis Pragae, Series $B$ - historia naturalis $57(1-2), 1-49$.

MERGL, M. 2002. Linguliformean and craniiformean brachiopods of the Ordovician (Třenice to Dobrotivá Formations) of the Barrandian, Bohemia. Acta Musei nationalis Pragae, Series $B$ - historia naturalis 58(1-2), 1-82.

MERGL, M. 2006. A review of Silurian discinoid brachiopods from historical British localities. Bulletin of Geosciences 81(4), 215-236. DOI 10.3140/bull.geosci.2006.04.215

MERGL, M. 2008. Lingulate brachiopods from the Acanthopyge Limestone (Eifelian) of the Barrandian, Czech, Republic. Bulletin of Geosciences 83(3), 281-298.

DOI 10.3140/bull.geosci.2008.03.281

MERGL, M. \& FERROVÁ, L. 2009. Lingulate brachiopods from the Chýnice Limestone (upper Emsian) from Čeřinka hill near Bubovice (Barrandian; Czech Republic). Bulletin of Geosciences 84(3), 525-546. DOI 10.3140/bull.geosci.1143

Mergl, M. \& MASSA, D. 1992. Devonian and Lower Carboniferous Brachiopods and Bivalves from Western Libya. Biostratigraphie du Paléozoique 12, 1-115.

Mergl, M. \& MASSA, D. 2004. Devonian Brachiopods of the Tamesna Basin (Central Sahara; Algeria and North Niger). Part 1. Acta Musei nationalis Pragae, Series B - natural history 60(3-4), 61-112.

MERGL, M. \& MASSA, D. 2005. A new giant discinoid brachiopod from the Lower Devonian of Algeria. Acta Palaeontologica Polonica 50(2), 397-402.

MuIR-WoOD, H.M. 1936. Brachiopoda from the lower Lias, Green Ammonite Beds, of Dorset. Quarterly Journal of the Geological Society of London 92, 472-487. DO] 10.1144/GSL.JGS.1935.091.01-04.23 
OтTO, M. 2000. Supposed soft tissue preservation in the Hunsrückschiefer (Lower Devonian, Rheinisches Schiefergebirge, the example of brachiopods. Paläontologische Zeitschrift 74, 79-89.

PACHECO, A. \& GARATE, A. 2005. Bioincrustantes en estructuras de cultivo de Argopecten purpuratus en bahía Samanco, Perú. Ecologia Aplicada 4(1/2), 149-152.

PAINE, R.T. 1962. Filter-feeding pattern and local distribution of the brachiopod Discinisca strigata. Biological Bulletin 123(3), 597-604. DO1 10.2307/1539581

PHILLIPS, J. 1836. Illustrations of the Geology of Yorkshire; or a description of the strata and organic remins: accompanied by a geological map, sections and diagrams and figures of the fossils, Part II, The Mountain Limestone District. xx + 235 pp. John Murray, London.

REEVE, L. 1862. Monograph of the genus Orbicula, pl. 1. In REEVE, L. Conchologia iconica.Vol. 13. L. Reeve \& Co., London.

RICHARDS, R.P. 1974. Mississippian discinid brachiopods attached to a soft-bodied organism. The Ohio Journal of Science 74(3), 174-181.

RICHARDSON, J.R. 1997. Ecology of articulated brachiopods, 441-472. In Williams, A., BRUNTON, C.H.C. \& CARLSON, S.J. (eds) Treatise on Invertebrate Paleontology, part $\mathrm{H}$, Brachiopoda, Revised, Volume 1. Geological Society of America, Inc. \& University of Kansas Press, Boulder \& Lawrence.

ROBISON, J.H. \& LEE, D.E. 2008. Brachiopod pedicle traces: recognition of three separate types of trace and redefinition of Podischnus centrifugalis Bromley \& Surlyk, 1973. Fossils and Strata 54, 219-225.

Rowell, A.J. 1965. Inarticulata, H260-H269. In MoORE, R.C. Treatise on Invertebrate Paleontology, part H, Brachiopoda, Volume 1. Geological Society of America \& University of Kansas Press, Boulder \& Lawrence.
SEILD, K. \& RÖHLICH, P. 1984. Explanatory Booklet, Geological Map of Libya, 1/250,000 (NG 33-2), Sheet Sabha, 1-138. Industrial Research Centre, Tripoli.

SOWERBY, G.B. 1822. Remarks on the genera Orbicula and Crania of Lamarck, with description of two species of each genus; and some Observations proving the Patella distorta of Montagu to be a species of Crania. Transactions of the Linnean Society of London 13, 465-472. DOI 10.1111/j.1095-8339.1821.tb00069.x

SOWERBY, G.B. 1846. The Recent Brachiopoda, 221-406. In Thesaurus Conchyliorum, or Monographs of genera of shells, Pt. 6, 7. London.

SÜDKAMP, W.H. 1997. Discovery of soft parts of a fossil brachiopod in the "Hünsruckschiefer" (Lower Devonian), Germany. Paläontologische Zeitschrift 7(1-2), 91-95.

THOMSON, M.R.A. 1971. Inarticulate Brachiopoda from the Lower Cretaceous of south-eastern Alexander Island. British Antarctic Survey Bulletin 25, 85-94.

VAlentine, J.L., BRock, G.A. \& Molloy, P.D. 2003. Linguliformean brachiopod faunal turnover across the Ireviken Event (Silurian) at Boree Creek, central-western New South Wales, Australia, 301-327. In KÖNIGSHOF, P. \& SCHINDLER, E. (eds) Mid-Palaeozoic bio- and geodynamics: the north Gondwana-Laurasian interaction. Courier Forschungsinstitut Senckenberg 242.

Williams, A., LUTER, C. \& CUSACK, M. 2001. The nature of siliceous mosaics forming the first shell of the brachiopod Discinisca. Journal of Structural Biology 134, 25-34. DOI $10.1006 /$ jsbi.2001.4366

ZEZINA, O.N. 1961. Distribution of the deep water brachiopod Pelagodiscus atlanticus (King). Okeanology 5(2), 354-358. [in Russian] 